\title{
Individual and combined effects of ice sheets and precession on MIS-13 climate
}

\author{
Q. Z. Yin, A. Berger, and M. Crucifix \\ Institut d'Astronomie et de Géophysique G. Lemaître, Université catholique de Louvain, Chemin du Cyclotron 2, \\ 1348 Louvain-la-Neuve, Belgium
}

Received: 23 January 2009 - Published in Clim. Past Discuss.: 24 February 2009

Revised: 1 June 2009 - Accepted: 2 June 2009 - Published: 24 June 2009

\begin{abstract}
An Earth System Model of Intermediate Complexity is used to investigate the role of insolation and of the size of ice sheets on the regional and global climate of marine isotope stage (MIS) 13. The astronomical forcing is selected at two dates with opposite precession, one when northern hemisphere $(\mathrm{NH})$ summer occurs at perihelion (at $506 \mathrm{ka}$ (1 ka=1000 years) BP, ) and the other when it occurs at aphelion (at $495 \mathrm{ka} \mathrm{BP}$ ). Five different volumes of the Eurasian ice sheet (EA) and North American ice sheet (NA), ranging from 0 to the Last Glacial Maximum (LGM) one, are used. The global cooling due to the ice sheets is mainly related to their area, little to their height. The regional cooling and warming anomalies caused by the ice sheets intensify with increasing size. Precipitation over different monsoon regions responds differently to the size of the ice sheets. Over North Africa and India, precipitation decreases with increasing ice sheet size due to the southward shift of the Intertropical Convergence Zone (ITCZ), whatever the astronomical configuration is. However, the situation is more complicated over East Asia. The ice sheets play a role through both reducing the land/ocean thermal contrast and generating a wave train which is topographically induced by the EA ice sheet. This wave train contributes to amplify the Asian land/ocean pressure gradient in summer and finally reinforces the precipitation. The presence of this wave train depends on the combined effect of the ice sheet size and insolation. When $\mathrm{NH}$ summer occurs at perihelion, the EA is able to induce this wave train whatever its size is, and this wave train plays a more important role than the reduction of the land/ocean thermal contrast. Therefore, the ice sheets reinforce the summer precipitation over East China whatever their sizes are. However, when NH summer occurs at aphelion, there is a threshold in the ice volume beyond which the wave train is
\end{abstract}

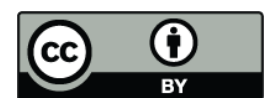

Correspondence to: Q. Z. Yin (yin@astr.ucl.ac.be) not induced anymore. Therefore, below this threshold, the wave train effect is dominant and the ice sheets reinforce precipitation over East China. Beyond this threshold, the ice sheets reduce the precipitation mainly through reducing the land/ocean thermal contrast.

\section{Introduction}

The ice sheets are among the largest topographic features on the Earth. They create regional anomalies in albedo and radiation balance, which have a strong influence on climate. Ice sheets actively interact with the rest of the climate system by amplifying and potentially driving global climate change. Direct and indirect influences of ice sheets on climate cause changes in oceanic and continental surface temperatures, in oceanic and atmospheric circulations, in the hydrological cycle, in vegetation, and in land surface albedo which, in turn, cause additional feedbacks in the climate system. In addition, modeling experiments have shown that the introduction of ice sheets can change atmospheric circulations, locally and remotely via planetary waves (Manabe and Broccoli, 1985; Kutzbach and Guetter, 1986; Felzer et al., 1996; Kageyama and Valdes, 2000; Chiang et al., 2003; Chiang and Bitz, 2005; Yin et al., 2008).

Many reconstructions have indicated such an influence of the ice sheets on monsoons and precipitation. According to de Menocal (1995), Africa climate and hydrology were regulated by low-latitude insolation forcing due to Earth orbital precession before the onset of the $\mathrm{NH}$ glaciation $\sim 2.8 \mathrm{MaBP}$. However, after 2.8 Ma BP, they became coincident with changes in the high-latitude ice sheets, indicating that they were probably driven by them. An et al. (2001) reported that the East Asian summer monsoon (EASM) recorded in the Chinese loess became more variable and at times weaker after 2.6 Ma BP. According to Clemens

Published by Copernicus Publications on behalf of the European Geosciences Union. 
et al. (1996), the phase between orbital forcing and Indian monsoon strength also changed around this time.

However, the relationship between monsoon and ice sheet is not necessarily as clear. On one hand, many terrestrial and marine records from Asia, Africa and surrounding oceans indicate a significant weakening of the summer monsoon during glacial times (Van Campo et al., 1982; Street-Perrott and Perrott 1990; An et al., 1991; Sirocko et al., 1991; Overpeck et al. 1996; Guo et al., 2000, 2009; Liu et al., 2003). Similarly, many modeling experiments have shown that the combined effects of ice sheets, $\mathrm{CO}_{2}$ and insolation at the LGM cause together a large reduction in monsoon precipitation as compared to today (Kutzbach et al., 1998; Braconnot et al., 2000; Kitoh et al., 2001; Yanase and Abe-Ouchi, 2007). Modeling simulations (Barnett et al., 1989; Vernekar et al., 1995) have also shown that an anomalously high Eurasian snow cover leads to a weaker monsoon over India mainly through reducing the land/ocean temperature contrast. From modern observations, Goes et al. (2005) found that a decline of the Eurasian snow cover is linked to an intensifying Indian summer monsoon. On another hand, conflicting with the traditional notion that ice sheets reduce summer monsoon intensity, strengthened summer monsoon events have been recorded during some glacials. A strengthened EASM is recorded in the mollusk assemblages of the Chinese Loess Plateau during the glacials MIS-10 and -12 (Wu et al., 2007) and also during the stadial MIS-6.5, $175 \mathrm{ka}$ ago (Rousseau and Wu, 1999; Rousseau et al., 2009). Speleothem records from China document an EASM stronger during MIS-6.5 than during MIS-5.5 and -7.3 (Wang et al., 2008). During the same MIS-6.5, an unusual sapropel event occurred in the Eastern Mediterranean Sea (Rossignol-Strick, 1983; Mélières et al., 1997) which was interpreted as increasing discharge of the Nile River into the Mediterranean Sea, presumably indicating a strengthened African monsoon. This was confirmed by modeling experiments showing that the glacial conditions do not necessarily prevent high insolation to generate an increased monsoon activity during MIS6.5 (Masson et al., 2000). Consequently the question can be raised of to which extent the ice sheets influence the monsoons. Based on marine sediment records, Clemens et al. (1991) argued that precession-forced insolation changes are the major driver of monsoon strength, whereas glacial boundary conditions have played only a minor role in determining the timing and strength of the Arabian Sea monsoon.

If strengthened summer monsoon occurred during glacial times, it would not be surprising to have them also during cooler interglacials. MIS-13 is documented as a "cool" interglacial in the Antarctica ice-core records (Jouzel et al., 2007). Indirect evidences (Imbrie et al., 1984; Lisiecki and Raymo, 2005) indicate that the sea-level at MIS-13 was significantly lower than today. However, the terrestrial records in China indicate a strong EASM occurred during MIS-13 (Guo et al., 1998, 2009; Yin and Guo, 2006, 2008). Marine records also indicate unusually strong African and Indian monsoons at MIS-13 (Bassinot et al., 1994; Rossignol-Strick et al., 1998). Modeling results by Yin et al. (2008) show that high NH insolation at the peak of MIS-13, $506 \mathrm{ka}$ ago, causes much larger precipitation over the EASM region than at PreIndustrial time, and surprisingly, that the EA ice sheet reinforces the EASM through a topographically induced wave train.

All these results tend to show that the response of the monsoons to ice sheets depends on the ice-sheet size and location, on the different monsoon regions, and on the combined effects of insolation and ice sheets. It is therefore interesting to know whether the strengthening of precipitation over East China due to the EA ice sheet in Yin et al. (2008) holds for other ice volumes and astronomical configurations. Is there a threshold in the ice volume beyond which the ice sheets reduce the summer precipitation? What is the exact role played by the insolation in the relationship between the ice-sheets and the monsoons? What is the response of the precipitation from other monsoon regions to the different ice sheet and astronomical forcings? These questions will be investigated in this paper, focusing mainly on the sensitivity to the $\mathrm{NH}$ ice sheets volumes and to the importance of the astronomical configurations. The model and experiments will be described in Sect. 2. In an attempt to characterize the orbital signature of interglacials (Kukla et al., 1981), climate response to different astronomical forcings will be discussed in Sect. 3. In Sect. 4, the response of July temperature to different sizes of the EA and NA ice sheets will be investigated under two opposite precessional situations. In Sect. 5, the response of July precipitation to different sizes of the EA and NA ice sheets under the two opposite precessional situations will be discussed for different monsoon regions. Finally, conclusions will be drawn in Sect. 6 .

\section{The model and experiments}

An Earth system model of intermediate complexity, LOVECLIM (Driesschaert et al., 2007), is used to investigate the response of the climate to the astronomical, greenhouse gas and ice sheet forcings. The atmosphere (ECBilt), the ocean-sea ice (CLIO) and the terrestrial biosphere (VECODE) are interactively coupled, the oceanic carbon cycle, the Greenland and Antarctic ice sheets being prescribed to their presentday situation. ECBilt is a quasi-geostrophic atmospheric model with 3 levels in the vertical and a T21 horizontal resolution (Opsteegh et al., 1998). CLIO is a primitiveequation, free-surface ocean general circulation model coupled to a thermodynamic-dynamic sea ice model (Goosse and Fichefet, 1999). Its horizontal resolution is $3^{\circ}$ in longitude and latitude, and there are 20 levels along the vertical. VECODE is a reduced-form model of vegetation dynamics and of the terrestrial carbon cycle (Brovkin et al., 1997). It simulates the dynamics of two plant functional types (trees and grassland) at the same resolution as that of ECBilt. 
The ECBilt-CLIO-VECODE model has been used in a large number of climate studies (reference can be made in particular to http://www.knmi.nl/onderzk/CKO/ecbilt-papers.html).

LOVECLIM is, within the hierarchy of the Earth system models of intermediate complexity, a low-resolution general circulation model (Claussen et al., 2002). Its main advantage compared to more sophisticated general circulation models is that it is much faster, allowing to study the behavior of the coupled atmosphere-ocean-sea ice-land surface-ice sheet system over thousands of years (a run of 1000 years takes about 3 days on a workstation AMD Opteron 252/2.6 GHZ with 2 CPU dual core/4 GB RAM). The main simplification within LOVECLIM is the coarse resolution and the low level of complexity of some parameterizations. This leads to some limitations which are related, in particular to the prescribed cloudiness and the difficulty to simulate the atmospheric variability at low latitudes. Accordingly, the model results for the tropics should be treated with caution. In particular, the East Asian summer precipitation is underestimated and the low-level geopotential ridge over the North Pacific is shifted northward 10 degrees in latitude compared to observations (Yin et al., 2008). These weaknesses are most likely caused by insufficient spatial resolution and simplified convective physics. As a consequence, quantitative estimates of the effects of astronomical parameters and ice sheets on East Asian precipitation should not be interpreted too rigidly. Yet, LOVECLIM has proved to be a reasonably appropriate tool to identify teleconnections. Moreover, the synoptic systems for the East Asian monsoon region are of hybrid nature due to the existence of a very significant interaction between the monsoonal aircurrents and impacts from mid and high latitudes (Ding and Sikka, 2006). Along with its computing efficiency, this justifies using this model for a first qualitative assessment of the connections between ice sheets and sub-tropical dynamics by means of a series of sensitivity experiments. Moreover, the reliability of our results is tested on the basis of simulations with more sophisticated oceanatmosphere general circulation models (such experiments, which confirm our results, will be discussed in companion papers).

Two series of sensitivity experiments with different ice volumes have been done under two opposite precessional conditions (Table 1). They hold respectively for $506 \mathrm{ka} \mathrm{BP}$ when NH summer occurs at perihelion (a forcing for the interglacial MIS-13.13) and for $495 \mathrm{ka} \mathrm{BP}$ when NH summer occurs at aphelion (a forcing for the stadial MIS-13.12). The greenhouse gas concentrations (GHG) are quite stable over the whole MIS-13.1 (Siegenthaler et al., 2005; Spahni et al., 2005; Loulergue et al., 2008; Luthi et al., 2008). The difference between 506 and $495 \mathrm{ka} \mathrm{BP}$ being very small, the average over MIS-13.1 is used for both cases with a $\mathrm{CO}_{2}$ of 240 ppmv, allowing to limit the sensitivity analysis to the astronomical and ice sheets forcings only. The ice sheet volumes are estimated from the $\delta^{18} \mathrm{O}$ of the deep-sea sediments taken from different reconstructions (Imbrie et al.,
1984; Bassinot et al., 1994; Tiedemann et al., 1994; Shackleton, 2000; Lisiecki and Raymo, 2005) using the assumption that there is a linear relationship between $\delta^{18} \mathrm{O}$ and the total ice volume over the Earth. Effects of deep-ocean temperature on the $\delta^{18} \mathrm{O}$ are neglected here, and therefore the ice volume might be over estimated, which puts an upper limit to the ice volume reconstruction. This hypothesis has to be confirmed from an analysis of the precise role that the deep-ocean temperature plays on these $\delta^{18} \mathrm{O}$ records. In the mean time, these will be used to reconstruct the ice sheets prevailing around $500 \mathrm{ka}$ ago (MIS-13), assuming that the relationship between the $\delta^{18} \mathrm{O}$ excess and the ice volume excess at the LGM remains valid for such a time. The values for the LGM are selected because it is a period for which the ice sheets are best reconstructed.

Therefore:

$\Delta$ ice volume (at time $t)=\Delta$ ice volume (at LGM)

$$
\left.* \Delta \delta^{18} \mathrm{O} \text { (at time } t\right) / \Delta \delta^{18} \mathrm{O}(\text { at LGM) }
$$

where $\Delta$ refers to the deviation from present-day.

Based on different reconstructions (Imbrie et al., 1984; Bassinot et al., 1994; Tiedemann et al., 1994; Shackleton, 2000; Lisiecki and Raymo, 2005), $\Delta \delta^{18} \mathrm{O}$ varies between $0.24 \%$ (Lisiecki and Raymo, 2005) and $1.239 \%$ (Imbrie et al., 1984) over the whole MIS-13.1 (which includes MIS13.11 around $482 \mathrm{ka} \mathrm{BP}$ and MIS-13.13 around $501 \mathrm{ka} \mathrm{BP}$ ). At the same time, the ratio $b$ :

$b=\Delta \delta^{18} \mathrm{O}($ at time $t) / \Delta \delta^{18} \mathrm{O}($ at LGM $)$

varies from 0.134 (Lisiecki and Raymo, 2005) to 0.318 (Imbrie et al., 1984). The ice volume excess at the LGM is assumed to be $47.2 \times 10^{6} \mathrm{~km}^{3}$ (Peltier, 1994) but it actually varies around $47 \times 10^{6} \mathrm{~km}^{3}$ plus or minus a few million $\mathrm{km}^{3}$ depending on the reconstructions. The total ice volume excess during MIS-13.1 would therefore have varied from $6.3 \times 10^{6} \mathrm{~km}^{3}$ based on Lisiecki and Raymo (2005) to $16.43 \times 10^{6} \mathrm{~km}^{3}$ based on Shackleton (2000). Moreover, the impact of the uncertainty related to the ice volume excess at the LGM can be illustrated by using the lowest reconstructed ice volume for the EA (either by Lambeck et al., 2000 or by Peltier ICE 5G, 2004), the other ice sheets being kept to their Peltier (1994) values. Such an assumption leads to a LGM total ice volume excess of $40 \times 10^{6} \mathrm{~km}^{3}$. Combined with the smallest value of $b$, this leads to an absolute minimum of the total ice volume excess of $5.3 \times 10^{6} \mathrm{~km}^{3}$ over the whole MIS-13.1.

In the calculation of the volume of the individual ice sheets, the ratio between the volumes of EA and of NA is assumed to be constant in time and equal to about 2 (the LGM ice volume for EA being $11.9 \times 10^{6} \mathrm{~km}^{3}$ and for NA being $24.2 \times 10^{6} \mathrm{~km}^{3}$ in Peltier, 1994). The Greenland and Antarctica ice sheets were kept the same as for the present-day in all the simulations (the present-day ice volume is about $2.9 \times 10^{6} \mathrm{~km}^{3}$ for Greenland ice sheet and $24.7 \times 10^{6} \mathrm{~km}^{3}$ for Antarctica ice sheet (IPCC, 2007)). 
Table 1. Orbital parameters and ice volumes used for the experiments in this paper. The same greenhouse gases concentrations $\left(\mathrm{CO}_{2}=240\right.$ ppmv, $\mathrm{CH}_{4}=510$ ppbv and $\mathrm{N}_{2} \mathrm{O}=280$ ppbv $)$ are used in all these experiments.

\begin{tabular}{l|ccc}
\hline Orbital parameters & Exp. NO. & \multicolumn{2}{c}{ Ice volume $\left(10^{6} \mathrm{~km}^{3}\right)$} \\
\cline { 3 - 4 } & & EA & NA \\
\hline $506 \mathrm{ka} \mathrm{BP:}$ & Exp. 1 & 0 & 0 \\
eccentricity $=0.034046$ & Exp. 2 & 1.96 & 3.48 \\
obliquity $=23.377^{\circ}$ & Exp. 3 & 2.79 & 5.67 \\
longitude of perihelion $=274.05^{\circ}$ & Exp. 4 & 3.63 & 7.38 \\
NH summer at perihelion & Exp. 5 & 11.9 & 24.2 \\
\hline 495 ka BP: & Exp. 6 & 0 & 0 \\
eccentricity $=0.038638$ & Exp. 7 & 3.63 & 7.38 \\
obliquity $=23.903^{\circ}$ & Exp. 8 & 11.9 & 24.2 \\
longitude of perihelion $=97.82^{\circ}$ & & & \\
NH summer at aphelion & & & \\
\hline
\end{tabular}

The shape of the ice sheets was assumed to be axisymmetric. For a given maximum thickness, $h$, and a diameter of the circular basis at the ground, $l$, the volume of such ice sheet is given by:

$V=2 \pi h l^{2} / 15$

The thickness of the ice sheet at each grid point can be then calculated assuming that we know the relationship between $h$ and $l$ and the location of the ice sheet center. According to Paterson's model (Paterson, 1994), $h^{2}=a L(L=l / 2)$. Using a 2-parabolic ice sheet leads to:

$a=0.3562 V^{2} L^{-5}$

and its numerical value $7.4 \mathrm{~m}$, assumed to be a constant, is obtained using the NA ice sheet at the LGM (its volume $V$ and size $L$ are best known and taken here to be $24.2 \times 10^{6} \mathrm{~km}^{3}$ and $1950 \mathrm{~km}$ respectively).

Finally, the centers of the small ice sheets (Exp. 2, 3, 4 and 7, Table 1) are supposed to be $90^{\circ} \mathrm{W}$ and $69^{\circ} \mathrm{N}$ for NA, and $50^{\circ} \mathrm{E}$ and $63^{\circ} \mathrm{N}$ for EA. These locations do not correspond to the LGM ones. They are tentatively related to the position that these ice sheets had during their development leading to the LGM ones. For the large ice sheets scenario (Exp. 5 and $8)$, the center of NA is located at its LGM position $\left(84^{\circ} \mathrm{W}\right.$, $58^{\circ} \mathrm{N}$ ), but the EA center is kept the same as in the small volume cases in order to have a better comparison between them. Sensitivity experiments where the EA ice sheet has been moved westward by $1000 \mathrm{~km}$ to finally be placed over Scandinavia, shows that this change of the EA location does not change the conclusion (Yin et al., 2008).

To test the influence of different sizes of ice sheets on the climate under different astronomical configurations, the astronomical forcing at 506 and $495 \mathrm{kaBP}$ has been selected (Berger, 1978), these dates both belonging to MIS-13.1. Two groups of experiments have been made (Table 1). One

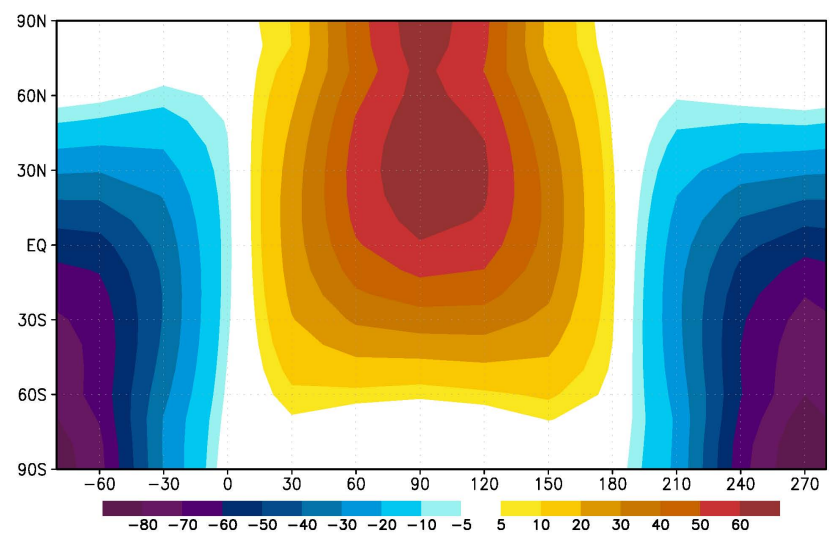

Fig. 1. Difference in the latitudinal and seasonal insolation $\left(\mathrm{Wm}^{-2}\right)$ distribution between 506 and $495 \mathrm{ka} \mathrm{BP}$. Labels on the X-axis indicate the true longitude of the Sun from the beginning to the end of the year. Insolation is calculated from the long-term variations of eccentricity, precession and obliquity (Berger, 1978; Berger et al., 1993).

is under the astronomical forcing at $506 \mathrm{ka} \mathrm{BP}$ (NH summer is at perihelion) with ice volumes of 1.96, 2.79, 3.63 and $11.9 \times 10^{6} \mathrm{~km}^{3}$ for EA, and of $3.48,5.67,7.38$ and $24.2 \times 10^{6} \mathrm{~km}^{3}$ for NA. The first three pairs of values are reconstructed from the $\delta^{18} \mathrm{O}$ records of Bassinot et al. (1994), Lisiecki and Raymo (2005) and SPECMAP (Imbrie et al., 1984), respectively. The largest volumes are from the LGM given by Peltier (1994). The other group is under the astronomical forcing at $495 \mathrm{ka} \mathrm{BP}$ (NH summer is at aphelion), with ice volumes of 3.63 and $11.9 \times 10^{6} \mathrm{~km}^{3}$ for EA and of 7.38 and $24.2 \times 10^{6} \mathrm{~km}^{3}$ for NA. Only two ice volumes were used for $495 \mathrm{ka} \mathrm{BP}$ because the experience gained from the 506-ka-BP four simulations shows that most of the conclusions can be drawn from these two experiments only. Experiments with no EA nor NA (Exp. 1 and 6) are used as references.

\section{Climate response to the astronomical forcing}

At $506 \mathrm{kaBP}$, the daily mean insolation is larger than at $495 \mathrm{kaBP}$ from the spring equinox to the fall equinox (Fig. 1). The maximum anomaly amounts to about $70 \mathrm{Wm}^{-2}$ and is centered at $30^{\circ} \mathrm{N}$ at the summer solstice reflecting the impact of a smaller obliquity at $506 \mathrm{ka} \mathrm{BP}$. The reverse is true between the fall equinox and the spring equinox with a maximum negative anomaly of $90 \mathrm{Wm}^{-2}$ centered at the South Pole.

As in previous experiments made with $\mathrm{NH}$ summer occurring at perihelion or at aphelion (Crucifix and Loutre, 2002), the latitudinal and seasonal distribution of insolation is reflected in our simulated surface temperature pattern. At $506 \mathrm{ka} \mathrm{BP}$, July is globally warmer and January cooler than both at $495 \mathrm{ka} \mathrm{BP}$ and Pre-Industrial time. In global and 
annual average, the Earth is warmer at $506 \mathrm{ka} \mathrm{BP}$ than at $495 \mathrm{ka} \mathrm{BP}\left(15.9^{\circ} \mathrm{C}\right.$ vs. $\left.15.5^{\circ} \mathrm{C}\right)$ but cooler than during PreIndustrial time $\left(16.1^{\circ} \mathrm{C}\right.$, simulated by LOVECLIM). The difference between 506 and $495 \mathrm{ka} \mathrm{BP}$ is only due to the insolation forcing, whereas the difference between these experiments and Pre-Industrial is due to both the insolation and a reduced $\mathrm{CO}_{2}$ concentration. The Earth warms more during $\mathrm{NH}$ summer at $506 \mathrm{ka} \mathrm{BP}$ (July: $+0.8^{\circ} \mathrm{C}$ above Pre-Industrial time) than during southern hemisphere (SH) summer (January: $-0.1^{\circ} \mathrm{C}$ ) at $495 \mathrm{ka} \mathrm{BP}$. Similarly, the Earth cools more (January: $-1.1^{\circ} \mathrm{C}$ ) during NH winter at $506 \mathrm{ka}$ BP than during SH winter at $495 \mathrm{ka} \mathrm{BP}\left(\mathrm{July}:-0.8^{\circ} \mathrm{C}\right)$. The annual mean temperature $0.4^{\circ} \mathrm{C}$ higher at $506 \mathrm{ka} \mathrm{BP}$ than at $495 \mathrm{ka} \mathrm{BP}$ indicates that the Earth is warmer when NH summer occurs at perihelion rather than at aphelion. Our experiments with opposite precessional conditions for the last 6 interglacials confirm such a result, implying that the NH response affects more effectively the globally averaged temperature. The PreIndustrial situation is a good illustration: when $\mathrm{NH}$ summer occurs at aphelion, the Earth is globally $4.3^{\circ} \mathrm{C}$ warmer during July than during January, although the Earth is in July $3.4 \%$ further away from the Sun (it means receiving globally $6.8 \%$ less energy from the Sun). Perhaps even more illustrative, both data and model results show that the NH during its local summer is warmer than the SH during its local summer by $\sim 5$ to $6^{\circ} \mathrm{C}$, and the $\mathrm{NH}$ during its winter is cooler than the $\mathrm{SH}$ during its winter by $\sim 2$ to $3^{\circ} \mathrm{C}$, leading to a seasonal contrast twice as large in $\mathrm{NH}\left(\sim 13^{\circ} \mathrm{C}\right)$ than in $\mathrm{SH}\left(\sim 6^{\circ} \mathrm{C}\right)$. There are three contributors to this difference: (1) the larger thermal inertia of the $\mathrm{SH}$; (2) due to its larger continental fraction, the $\mathrm{NH}$ is the seat of more radiative feedbacks than the $\mathrm{SH}$; and (3) in the $\mathrm{SH}$, more solar energy is converted into latent heat, which damps the temperature response.

The details of these features can be seen in Fig. 2a, which gives the geographical distribution of the difference between 506 and $495 \mathrm{ka} \mathrm{BP}$ for the July surface temperature (Exp. 1Exp. 6). This shows maxima reaching $15^{\circ} \mathrm{C}$ over northern North America and over the Tibetan Plateau, $10^{\circ} \mathrm{C}$ over northeastern Asia, 5 to $7^{\circ} \mathrm{C}$ along the west coast of North America, over North Africa and the Near East, 4 to $5^{\circ} \mathrm{C}$ over most of South America, Australia, central to south Africa, and over the Antarctic ocean. This represents a considerable cooling of the whole Earth in July, when going from the peak of MIS 13 (MIS-13.13) to the stadial MIS-13.12, $11 \mathrm{ka}$ later.

For January, going from 506 to $495 \mathrm{ka} \mathrm{BP}$, the warming over the continents reaches $4^{\circ} \mathrm{C}$ in the $\mathrm{SH}$ over Australia and South America (the reverse of what happens in July), but barely $2^{\circ} \mathrm{C}$ over Eurasia and about $0^{\circ} \mathrm{C}$ in North America (Exp. 6-Exp. 1, the opposite of Fig. 2b where Exp. 1Exp. 6 is plotted). This increasing seasonal contrast in the $\mathrm{SH}$, opposed to what happens in the $\mathrm{NH}$, results also directly from the orbital configuration: July (i.e. $\mathrm{NH}$ summer and $\mathrm{SH}$ winter) switches from perihelion (at $506 \mathrm{ka} \mathrm{BP}$ ) to aphelion (at $495 \mathrm{ka} \mathrm{BP}$ ), at the same time that January switches from aphelion to perihelion. But more surprising is the Jan-
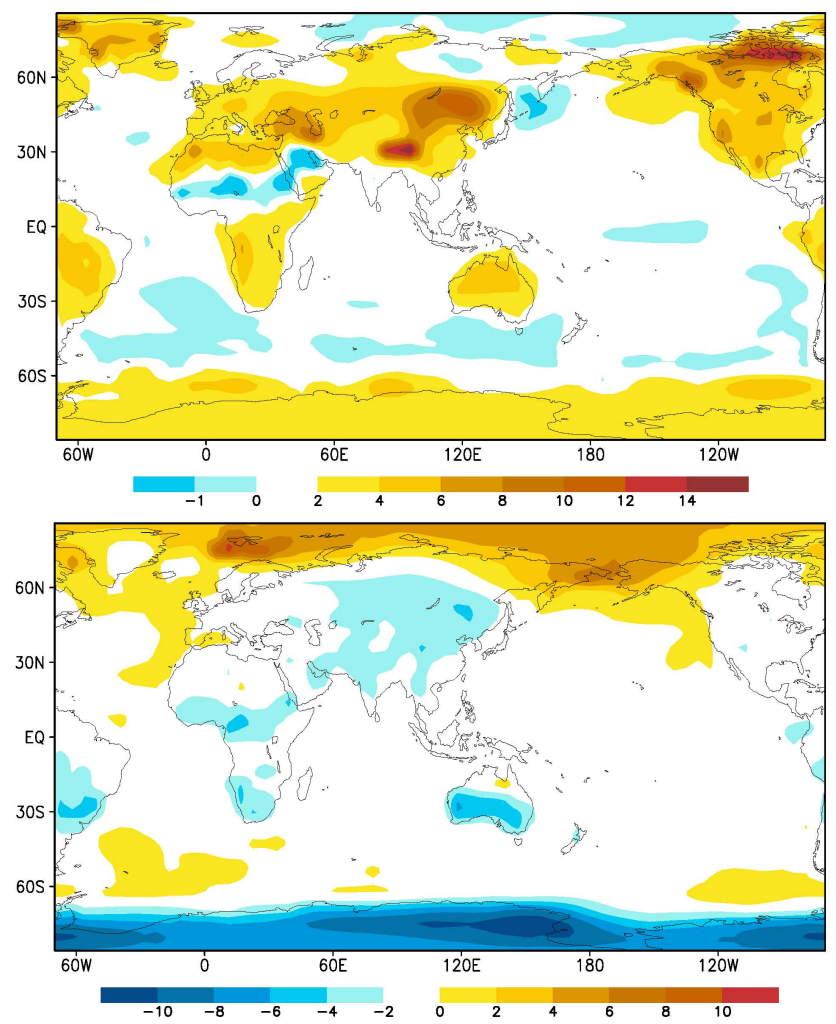

Fig. 2. Difference of July (a)(upper panel) and January (b)(lower panel) surface temperature between 506 and $495 \mathrm{ka} \mathrm{BP}$ with no EA nor NA ice sheets (Exp. 1 minus Exp. 6).

uary cooling all over the Arctic Ocean, with two deep centers located around the Bering Strait and between Greenland and North Scandinavia at $495 \mathrm{ka} \mathrm{BP}$ when compared to $506 \mathrm{ka} \mathrm{BP}$. Over the northern North Atlantic, a cooling of more than $8^{\circ} \mathrm{C}$ occurs and the large sea-ice cover is responsible for the deep-water formation to move south. This is actually due to the cold NH summer of $495 \mathrm{ka} \mathrm{BP}$ which makes ice to persist all through the summer season over the Arctic Ocean allowing it to be present during the next warm winter.

Analysis of the sea surface temperature shows clearly that sea surface in July (January) is warmer (cooler) at $506 \mathrm{ka} \mathrm{BP}$ than at $495 \mathrm{ka} \mathrm{BP}$ almost everywhere. In July, it is more than $3^{\circ} \mathrm{C}$ warmer over the northeastern North Pacific and $1-2^{\circ} \mathrm{C}$ over the central North Pacific. Over the equatorial Pacific, a cold tongue anomaly resembles more or less to a La Niña situation. It is $1-3^{\circ} \mathrm{C}$ warmer in the mid-high latitudes of the North Atlantic and it is $1-2^{\circ} \mathrm{C}$ cooler over the South Atlantic.

The sensitivity of precipitation to the astronomical and greenhouse gas forcings has been analyzed in Yin et al. (2008). It showed, in particular, more precipitation over all the northern monsoon regions in $\mathrm{NH}$ summer at 506 than at $495 \mathrm{ka} \mathrm{BP}$ due to the larger $506 \mathrm{ka} \mathrm{BP}$ insolation during the summer season. This is in consistent with the recent results of Liu et al. (2006) and Kutzbach et al. (2008) who found 

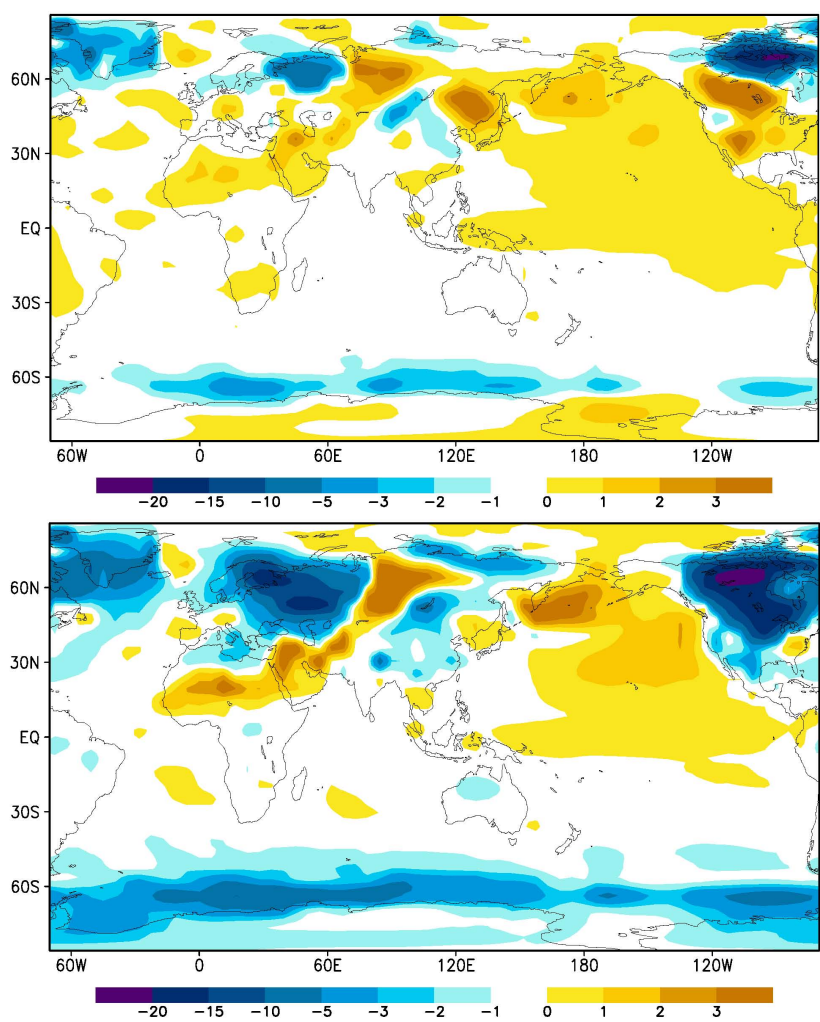

Fig. 3. Difference in July surface temperature $\left({ }^{\circ} \mathrm{C}\right)$ at $506 \mathrm{ka} \mathrm{BP}$ between experiment with and experiment without NA and EA ice sheets. (a)(upper panel) for small ice sheets, Exp. 4 minus Exp. 1; (b)(lower panel) for large ice sheets, Exp. 5 minus Exp. 1.

a strong and positive response of northern summer monsoon precipitation to northern summer insolation forcing.

\section{July surface temperature response to the ice sheets}

Most of the earlier simulations done with NH ice sheets were for the LGM. In this paper the ice sheets are introduced in an interglacial and the climate sensitivity to them is therefore assumed to be different. Moreover the sensitivity during a warm phase (NH summer at perihelion) is compared to the sensitivity during a cool phase ( $\mathrm{NH}$ summer at aphelion) in the presence of the same ice sheets.

\subsection{6 ka BP}

When compared to the no EA or NA experiment (Exp. 1), the small ice sheets (Exp. 4) cool the Earth by $0.4^{\circ} \mathrm{C}$ annually, by $0.6^{\circ} \mathrm{C}$ in January and by $0.2^{\circ} \mathrm{C}$ in July. The largest impact is over the ice sheets with a cooling of up to $7^{\circ} \mathrm{C}$ over the EA ice sheet and $21^{\circ} \mathrm{C}$ over the NA ice sheet (Fig. 3a). In addition, there are three regions in the $\mathrm{NH}$ which get cooler under the influence of these ice sheets. This cooling amounts to $1-4^{\circ} \mathrm{C}$ over Greenland and to $1-2^{\circ} \mathrm{C}$ over both the Taymyr Penin- sula and the Altai-western Mongolia mountain regions from where it extends up to East China. In the $\mathrm{SH}$, the winter surface of the Antarctic Ocean cools by $1-3^{\circ} \mathrm{C}$. Our sensitivity experiments show that the reduced global mean temperature is mainly due to the albedo, and little to the height. This is consistent with the result of Felzer et al. (1996) but with a slab-ocean model. The cooling over high-latitudes is mainly due to increasing snow area, sea-ice fraction and albedo, underlining their importance in polar climate change (Kukla and Kukla, 1974). However, the snow field and albedo do not significantly change over the mid-latitudinal Altai-western Mongolia regions. The cooling over there might be due to the ascent of air generated over these elevated regions by the introduction of the ice sheets.

The reasons for differentiated coolings over the EA and NA ice sheets need also to be investigated. The ice sheets in the model are characterized by their height, area and albedo. The most direct cause for temperature anomalies over the ice sheets arises from changes related to their volume and location. The Stein-Alpert factor separation method (Stein and Alpert, 1993) shows that roughly half of the local cooling over the EA ice sheet is due to the albedo effect, the other half to topography. Assuming this holds for the NA ice sheet as well would explain part of the difference between the cooling over the EA and NA ice sheets. The area of the NA ice sheet being almost $80 \%$ larger than the area of the EA ice sheet and its summit $300 \mathrm{~m}$ higher would indeed lead to an additional cooling of about $7^{\circ} \mathrm{C}$ over its surface. This is less than the simulated $21^{\circ} \mathrm{C}$ cooling. Therefore, circulation changes might also be involved. In July, the Asian jet develops in the upper troposphere (Fig. 4a). The jet core with zonal winds exceeding $20 \mathrm{~ms}^{-1}$ exists in the mid-latitudes $\left(50\right.$ to $\left.60^{\circ} \mathrm{N}\right)$ of the Eurasian and North American continents. The Asian jet is strong enough to be a waveguide (Enomoto et al., 2003). The meridian wind distribution (Fig. 4b) implies the existence of stationary waves on the jet, southerlies and northerlies alternating every $2500 \mathrm{~km}$ in global average. Over the Eurasian continent, the stationary wave train appears to be initiated near the jet entrance (at about $20^{\circ} \mathrm{E}$ ) and to propagate along the jet. With the small ice sheet of Exp. 4 for example, the jet moves south by a few degrees (Fig. 4c), but intensifies mainly over Europe and slightly over North America, whereas it weakens over the central Siberian Plateau. At the same time, the northerlies over the western and central parts of the NA ice sheet intensify and so does the southerly component of the wind over the whole EA ice sheet (Fig. 4d). This supports the hypothesis that the limited cooling over EA and the strong one over NA are also resulting from changes in horizontal advection. This is in line with the omega field at $650 \mathrm{hPa}$, which becomes significantly more negative over the EA ice sheet (convergence) and more positive over the NA (subsidence, divergence).

In addition to the general cooling, the ice sheets also introduce a warming over a region extending from West Africa to the East of the EA ice sheet, the Western Siberian Lowlands. 

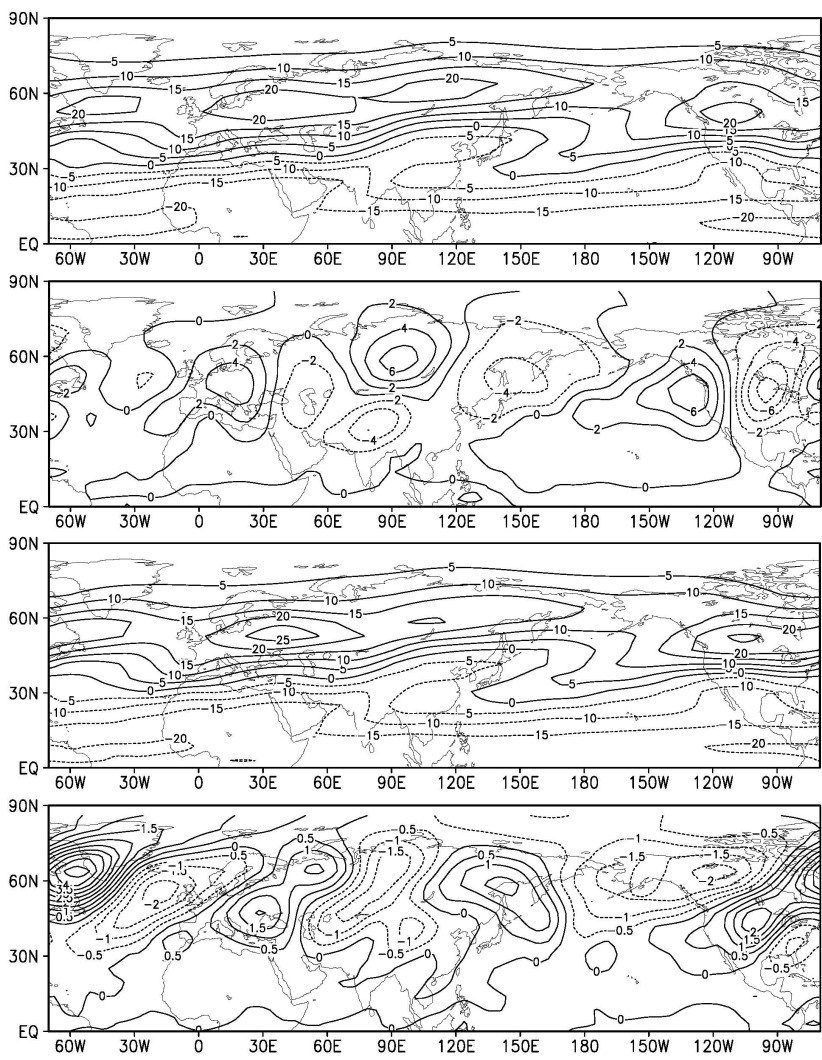

Fig. 4. Sequentially from the top to the bottom, the panels are: (a)July $200 \mathrm{hPa}$ zonal wind (m/s) for Exp. 1 (506 ka BP without ice sheet), (b)same as (a) but for meridianal wind, (c)July $200 \mathrm{hPa}$ zonal wind $(\mathrm{m} / \mathrm{s})$ for Exp. 4 (506 ka BP with small ice sheet), (d)Difference in July $200 \mathrm{hPa}$ meridianal wind between Exp. 4 and Exp. 1 (Exp. 4 minus Exp. 1).

This warming continues to the north of the Pacific Ocean through northeastern Asia where the temperature increases by $1-4^{\circ} \mathrm{C}$. A similar warming occurs also over a large region south of the NA ice sheet. Many LGM simulations have produced a downstream summer temperature larger than present day south of the EA (Kutzbach and Guetter, 1986; Rind, 1987), or south of both the NA and EA (Manabe and Broccoli, 1985; Felzer et al., 1996). The mechanisms responsible for the downstream warming are generally attributed to lower (than modern) glacial land albedo south of the NA ice sheet, to lower elevations south of the EA ice sheet (Manabe and Broccoli, 1985), and to subsidence of air flowing off of the ice sheets (Rind, 1987). In our simulations, the warming east and southeast of EA might result from the subsidence of air flowing off of the ice sheet, because the surface wind over the upstream of the EA ice sheet is westerly and northwesterly, and the air flowing off of the ice sheet will subside as it flows downhill, resulting in winds that warm adiabatically immediately leeward of the ice sheet. However, this does not help to explain the warming over North Africa, the Middle East and northeastern Asia, because these regions are far away from the EA ice sheet but they correspond to regions of a low elevation. It can be explained by the fact that the introduction of ice sheets perturbs the atmosphere in a way that divergence and air subsidence reduce precipitation, decrease the latent heat, increase the sensible heat and therefore warm the surface.

When the large ice sheets are introduced (Exp. 5, Fig. 3b) the pattern of temperature change is similar to that resulting from the small ice sheets (Exp. 4, Fig. 3a), but the amplitude is larger. These large ice sheets cool the Earth by $1.1^{\circ} \mathrm{C}$ annually, $1.3^{\circ} \mathrm{C}$ in January and $1{ }^{\circ} \mathrm{C}$ in July. The temperature decreases by up to $18^{\circ} \mathrm{C}$ over the EA ice sheet and by up to $21^{\circ} \mathrm{C}$ over the NA ice sheet. As compared to the smallice-sheet case, the temperature over EA decreases considerably (its altitude increased by $700 \mathrm{~m}$ ). It is not the case over the NA ice sheet although its altitude increases by the same amount, but its center at the LGM is located south of its small-ice-sheet position preventing a further cooling. As expected, the cooling over Asia, Greenland, North Atlantic Ocean, the Arctic Ocean and the southern Ocean is larger than in the small-ice-sheet case. On the contrary, the belt from Africa to west Siberia low land becomes much warmer. The warming of $3^{\circ} \mathrm{C}$ previously centered over northeastern Asia in the small-ice-sheet-case is now shifted to the Northwest of the Pacific Ocean. Even more significant is the considerable reduction of the warm area south of the NA ice sheet. All these features are directly associated to the response of the general circulation of the atmosphere.

\section{$4.2495 \mathrm{ka} \mathrm{BP}$}

Annually at $495 \mathrm{kaBP}$, the Earth with small ice sheets (Exp. 7) is $0.1^{\circ} \mathrm{C}$ cooler than without ice sheets. The largest impact of the ice sheets on the surface temperature is still over the regions of the ice sheets themselves (Fig. 5a). In July, the cooling due to small ice sheets is up to $12^{\circ} \mathrm{C}$ over the $\mathrm{EA}$ and $16^{\circ} \mathrm{C}$ over the NA ice sheets. The main differences between 506 and $495 \mathrm{ka}$ BP occur over the Taymyr Peninsula and over the southern Ocean where the cooling is much larger at 495 than at $506 \mathrm{ka} \mathrm{BP}$. In the $495 \mathrm{ka} \mathrm{BP}$ no-ice-sheet experiment (Exp. 6), the Taymyr Peninsula is under the influence of south-easterly winds in July with a strong heat advection from the interior of the Asian continent. When the ice sheets are introduced, the meridional wind component becomes much weaker, allowing more snow and ice persisting through summer. However, at $506 \mathrm{ka} \mathrm{BP}$, when the ice sheets are introduced, the southerly wind component is strong enough to transport heat from low-latitudes, melting more snow and ice than at $495 \mathrm{kaBP}$. Compared to the 506 small-ice-sheet situation (Fig. 3a), the warming area in 495 is enlarged over the North Atlantic, the Tibetan Plateau, eastern Siberia, but largely shrinks over the region south of the NA ice sheet (Fig. 5a).

The large ice sheets at 495 cool the Earth by $1.1^{\circ} \mathrm{C}$ annually, $1.1^{\circ} \mathrm{C}$ in January and $1.3^{\circ} \mathrm{C}$ in July. The warming 

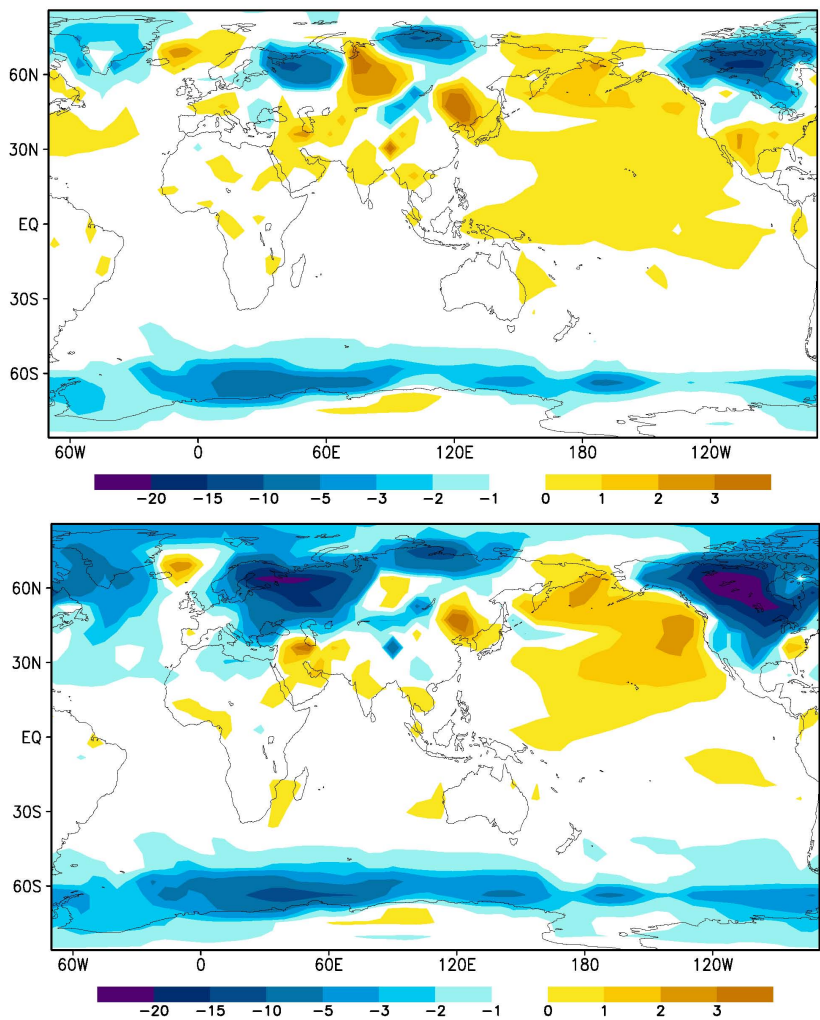

Fig. 5. Difference in July surface temperature $\left({ }^{\circ} \mathrm{C}\right)$ at $495 \mathrm{ka} \mathrm{BP}$ between experiment with and experiment without NA and EA ice sheets. (a) (upper panel) for small ice sheets, Exp. 7 minus Exp. 6; (b) (lower panel) for large ice sheets, Exp. 8 minus Exp. 6.

area observed in all the other experiments discussed above, largely shrinks and most of the Eurasian continent becomes cooler (Fig. 5b). This July cooling over the Eurasian continent due to the EA and NA ice sheets at $495 \mathrm{ka} \mathrm{BP}\left(0.3^{\circ} \mathrm{C}\right.$ for the small ice sheets and $2.4^{\circ} \mathrm{C}$ for the large ones) is larger than the cooling due to the same ice sheets at $506 \mathrm{ka} \mathrm{BP}$ (respectively 0.1 and $1.8^{\circ} \mathrm{C}$ ). It is thus seen that the effect of ice sheets on temperature is larger when the background climate is cooler, because a cooler climate creates the conditions for greater sea-ice and snow albedo feedbacks. The increases in snow area, sea ice and albedo over the high latitudes are the largest in Exp. 8.

\section{July precipitation}

Only the precipitation features significant at more than the 95\% confidence level (a measure based on t-test) are discussed in this section.

\section{$5.1506 \mathrm{ka} \mathrm{BP}$}

The Earth globally gets cooler and also drier when the ice sheets are introduced. The main pattern of precipitation
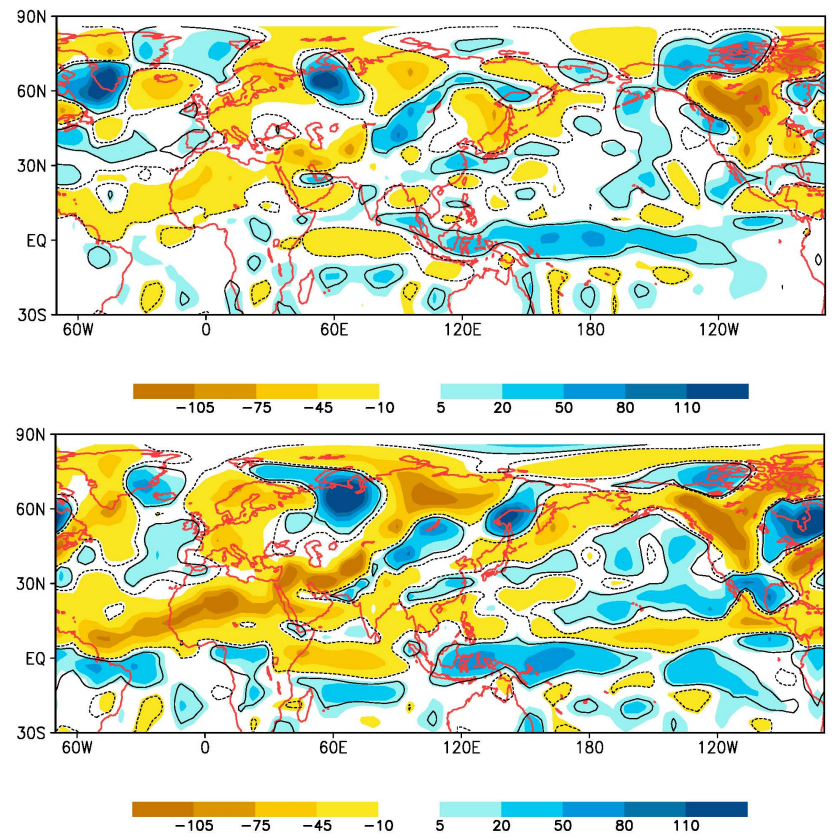

Fig. 6. July precipitation difference between experiment with and experiment without NA and EA ice sheets, for $506 \mathrm{ka} \mathrm{BP}$. (a) (upper panel) for small ice sheets, Exp. 4 minus Exp. 1; (b) (lower panel) for large ice sheets, Exp. 5 minus Exp. 1. The color shading indicates precipitation anomaly in $\mathrm{cm} /$ year and the black contour lines limit the regions where the anomalies are significant at more than the $95 \%$ confidence level.

changes is the same in all three experiments with "small" ice sheets (Exp. 2, 3 and 4). Upslope of the EA ice sheet, a drier zone results from anticyclongenesis due to the decrease of vorticity, and downslope of it a wetter zone appears related to cyclogenesis due to the increase of vorticity (Fig. 6a). Around the NA ice sheet, there are also wetter and drier zones, but their pattern is slightly more complicated due to the presence of the Greenland ice sheet immediately east of it. Over central North America, the precipitation is largely reduced. In the high latitudes, there is a succession of centers of positive and negative precipitation anomaly. These are thermodynamically induced by the modification of the albedo, sea ice and snow due to the introduction of the EA and NA ice sheets. In the mid and low latitudes, the most significant features are (1) a drier belt extending from the tropical western Atlantic to the eastern North Africa and most of the Middle East, (2) a wetter belt over Inner Asia extending from the south-west to the north-east, (3) a wetter belt over East China oriented from south-west to north-east and disappearing over the Pacific, (4) a wetter belt extending from the south of the Bay of Bengal, through the Indonesian islands and to the east over the whole equatorial Pacific, and (5) a wetter zone from west of Mexico to the western Atlantic. All the regions with precipitation increase (decrease) correspond to air ascent (descent). Away of the ice sheets, most of the 
wetter (drier) regions correspond to a surface temperature decrease (increase).

The fundamental driving mechanisms of monsoon include: (1) land/ocean thermal contrast and the resulting pressure gradient force between the differentially heated regions and (2) moisture-related processes that determine the strength and location of the monsoon precipitation (Webster et al., 1998). According to (1), one might expect that ice sheets, by cooling the continents, will induce a smaller land/ocean thermal contrast and so will contribute to reduce the monsoon rainfall. However, this is not the case over East China. Although the temperature gradient between the Asian land and the surrounding ocean gets indeed slightly smaller, July precipitation increases by $20 \%$ over East China relative to the no-ice-sheet case (Exp. 1). Consistent with the precipitation increase, the summer low at $800 \mathrm{hPa}$ deepens over a large area of Siberia-Mongolia-China, but at the same time pressure increases over a large region extending from northeastern China to Japan and up to the Pacific. These two pressure anomalies induce a westerly wind anomaly over western China and an easterly wind anomaly blowing from the sea to the land over East China, which converge over central China resulting in more convection there. At the same time, there is a significantly increase of water vapor flux convergence over East China. These intensified convection and moisture availability contribute to increase the precipitation.

These changes in precipitation, pressure and wind fields are also associated with a wave train originating from the EA ice sheet and propagating to the Southeast. This wave train is characterized by (1) an alternation of precipitation increase and decrease ending over East China with a reinforcement of precipitation (Fig. 6a), and (2) alternating positive (subsidence) and negative (ascent) omega anomalies ending over East China with a large scale ascent (not shown here). This wave train is also remarkably present in the wind divergence field. Our sensitivity experiments using either albedo or topography as the only forcing show that this wave train is mainly generated by the EA ice-sheet topography. The existence of this wave train is consistent with the results of Grose and Hoskins (1979) and Hoskins and Karoly (1981) showing that wave trains can be orographically generated in barotropic or baroclinic atmospheres. The phase lock of our wave train over East China is related to the summer low there and to the Tibetan Plateau (Yin et al., 2008). The increase of land/ocean pressure gradient due to the introduction of the ice sheets, opposite to what is expected from the decrease of the land/ocean thermal contrast, is therefore tentatively attributed to the topographically induced wave train.

The pattern of precipitation change is similar for the three experiments with small NA and EA ice sheets, but precipitation over East China increases by 14, 16 and $20 \%$ for the ice volume of 5.5 (Exp. 2), 8.5 (Exp. 3) and $1110^{6} \mathrm{~km}^{3}$ (Exp. 4), respectively. By contrast, this ice volume increase reduces progressively the precipitation over North Africa.

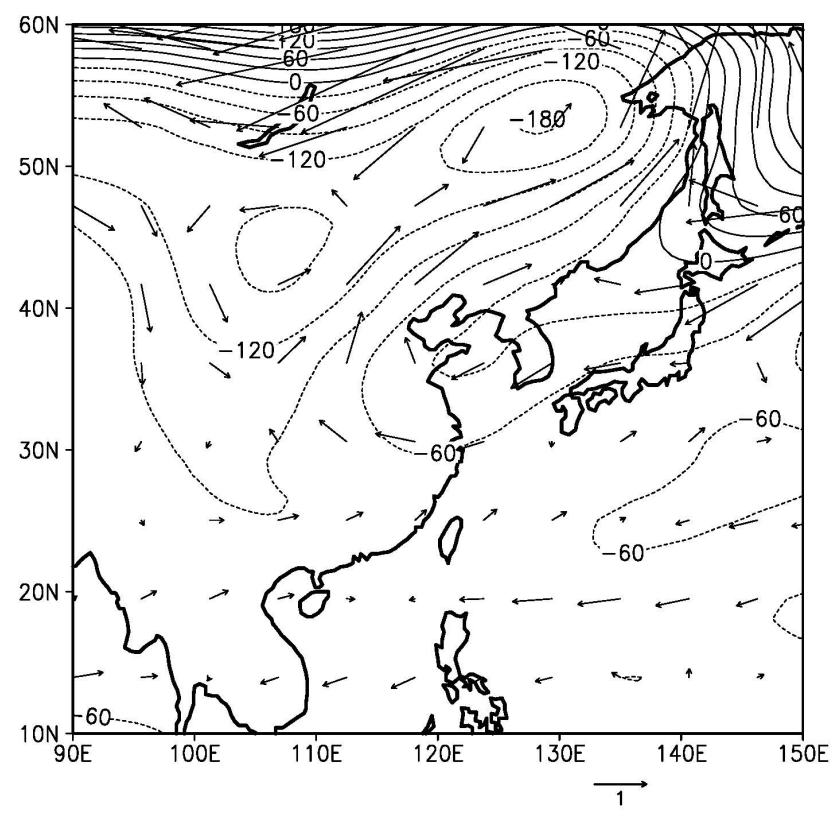

Fig. 7. Difference between Exp. 5 and Exp. 1 in July $800 \mathrm{hPa}$ geopotential $\left(\mathrm{m}^{2} \mathrm{~s}^{-2}\right)$ and wind $(\mathrm{m} / \mathrm{s})$ over East Asia.

Are these features holding if the ice sheets reach their maximum LGM size (Exp. 5)? Figure 6b shows the impact on July precipitation in this large-ice-sheet case with a volume of 24.2 and $11.9 \times 10^{6} \mathrm{~km}^{3}$ respectively for the NA and EA ice sheets. The pattern of precipitation change is generally consistent with that due to the small ice sheets, but globally the amplitude is much larger. Over East China, precipitation is larger than in the no-ice-sheet experiment. The large ice sheets cause an anticyclonic anomaly north of about $60^{\circ} \mathrm{N}$, but south of $60^{\circ} \mathrm{N}$ the thermal low deepens over most of the Eurasian continent (Fig. 7). Although the northwestern Pacific High weakens slightly, the land/sea pressure gradient remains larger than in Exp. 1. Consistently, there is a southeasterly wind anomaly blowing from the sea to the land over East China which reinforces the EASM (Fig. 7). The convergence of the water vapor flux over East China remains larger than in Exp. 1, which favors convective precipitation. This larger precipitation over East China is still associated with a wave train similar as in the small-ice-sheet cases with the same phase and wave-length although with a larger amplitude and further extension. Here the precipitation increase (14\%) relative to Exp. 1 is less than in Exp. 3 and Exp. 4. This is related to the fact that the large ice sheets cool the Asian continent more and the land/ocean thermal contrast gets even smaller than in the small-ice-sheet cases. This contributes to reduce the land/ocean pressure gradient, but not enough to counteract the effects of the wave train.

Although monsoon is emphasized as a global system, for example by considering it as a manifestation of seasonal migration of the ITCZ (Trenberth et al., 2006; Wang, 2009), 

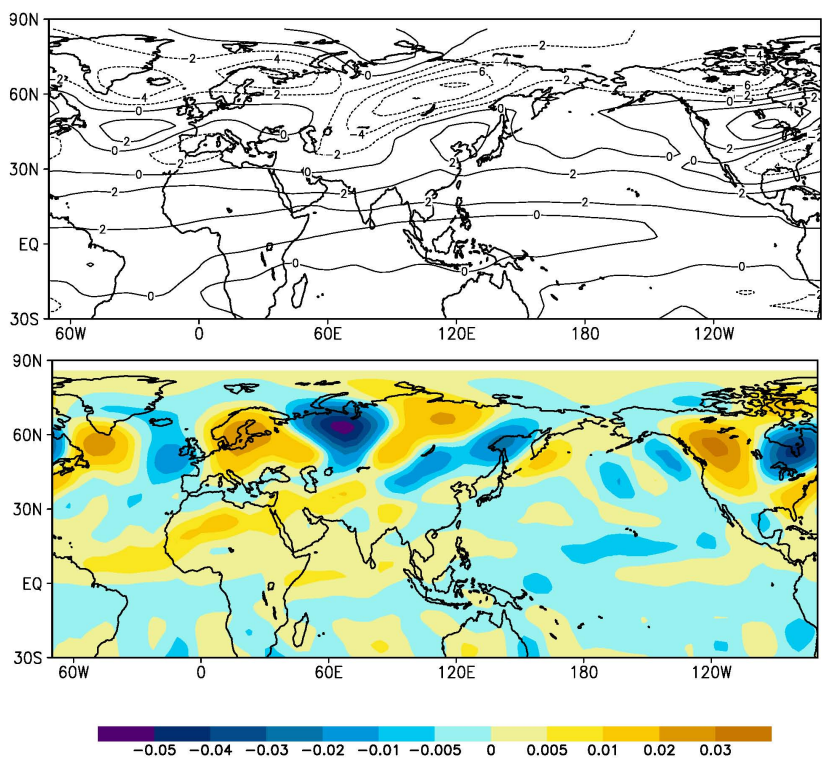

Fig. 8. (a)(upper panel) Difference between Exp. 5 and Exp. 1 in July $200 \mathrm{hPa}$ zonal wind (Exp. 5 minus Exp. 1), and (b)(lower panel) Difference between Exp. 5 and Exp. 1 in July $650 \mathrm{hPa}$ omega field.

different monsoon subsystems respond differently to the forcing due to, for example, the different land-ocean configuration and topography (Wang et al., 2003; Ding and Sikka, 2006). Over North Africa, July precipitation is largely reduced $(-24 \%)$ by the introduction of the large ice sheets (Exp. 5). This drier belt extends eastwards through the Indian subcontinent, over the South China Sea and around the whole $\mathrm{NH}$ tropics. South of it, there is a wetter belt over SH tropics up to $10^{\circ} \mathrm{S}$. The southward shift of the tropical rainfall maximum is associated with a southward migration of the ITCZ under the influence of the large ice sheets. These results are consistent with those obtained by Chiang et al. (2003), Broccoli et al. (2006) and Braconnot et al. (2007) where the ITCZ shifts southwards due to the NH dramatic cooling induced by the LGM ice sheets and with the hypothesis that the ITCZ should move towards the relatively warmer hemisphere in response to a differential cooling (Brocolli et al., 2006). In July, under the insolation and GHG forcings only, the Asian jet develops in the upper troposphere at about 50 to $60^{\circ} \mathrm{N}$. The jet core with zonal winds exceeding $20 \mathrm{~ms}^{-1}$ exists over the North of the Eurasian continent (Fig. 4a). When the EA and NA ice sheets are introduced, the mean position of the $200 \mathrm{hPa}$ zonal wind is also shifted southwards (Fig. 8a). There is a subsidence anomaly over most of the $\mathrm{NH}$ tropics and a slight ascent over the SH tropical region (Fig. 8b). This is similar to what Chiang and Bitz (2005) found with a shift meridionally away from the hemisphere with an imposed added ice sheet, altering the global Hadley cell circulation with an increase tropical subsidence in the hemisphere with imposed ice and uplift in the other. These migrations of the ITCZ and of the jet stream are more pronounced in the large-ice-sheet case than in the small ones.

In summary, the ice sheets always reinforce July precipitation over East China when the NH summer occurs at perihelion, whatever their sizes. The mechanism involves a topographically induced wave train by the EA ice sheet, which largely contributes to deepen the summer low over the Asian continent, and then reinforce the land/ocean pressure gradient, the easterly wind and the water vapor flux convergence over East China. Although the land/ocean thermal contrast gets slightly weaker when the ice sheets are introduced, this weakening is not sufficient to reduce significantly the land/ocean pressure gradient increase associated with the wave train. On the contrary, the ice sheets always reduce precipitation over North Africa through shifting the ITCZ southwards. The precipitation response to the ice sheets is much larger over North Africa than over Asia. Over India, the precipitation response depends on the ice sheet size. Small ice sheets reinforce precipitation over North India, but large ice sheets reduce it over most of India due to the significant southward migration of the ITCZ.

\section{$5.2495 \mathrm{ka} \mathrm{BP}$}

The only difference between the simulations at $506 \mathrm{kaBP}$ and $495 \mathrm{kaBP}$ is their astronomical configurations. In Sect. 3, we have shown that the continents are much warmer in summer at $506 \mathrm{ka} \mathrm{BP}$ than $495 \mathrm{kaBP}$ due to their insolation difference which is mainly attributed to their opposite precession. Therefore, comparing the impact of ice sheets on monsoon rainfall at $506 \mathrm{ka} \mathrm{BP}$ and $495 \mathrm{ka} \mathrm{BP}$ will give an idea on how the insolation plays a role on this impact of ice sheets.

Figure 9a shows July precipitation change under the influence of the small NA and EA ice sheets at $495 \mathrm{ka} \mathrm{BP}$ (Exp. 7 Exp. 6). The pattern of the precipitation change is similar to the $506 \mathrm{ka}$ BP small-ice-sheet case (Exp. 4-Exp. 1, Fig. 6a). The EA ice sheet generates again a wave train over the Eurasian continent. This wave train has almost the same phase and wave-length as in the $506 \mathrm{kaBP}$ case. The precipitation increase over East China is also of the same order of magnitude (20\%) but the total amount is only half of it because the climate at $495 \mathrm{ka} \mathrm{BP}$ is globally cooler and drier than at $506 \mathrm{ka} \mathrm{BP}$. On the other hand, the introduction of the small ice sheets causes a drier belt extending from North Africa through northern India to the South China Sea, and a slightly wetter condition over South India.

When the NA and EA ice sheets reach their LGM volume, July precipitation decreases over a large part of the Earth (Fig. 9b). In high latitudes, the pattern of precipitation change at $495 \mathrm{ka} \mathrm{BP}$ is similar to the impact of the large ice sheet at $506 \mathrm{kaBP}$, with large scale alternating precipitation increases and decreases. There are two main differences between 506 and $495 \mathrm{ka} \mathrm{BP}$. First, the southwards migration of the ITCZ due to the ice sheets is more pronounced 

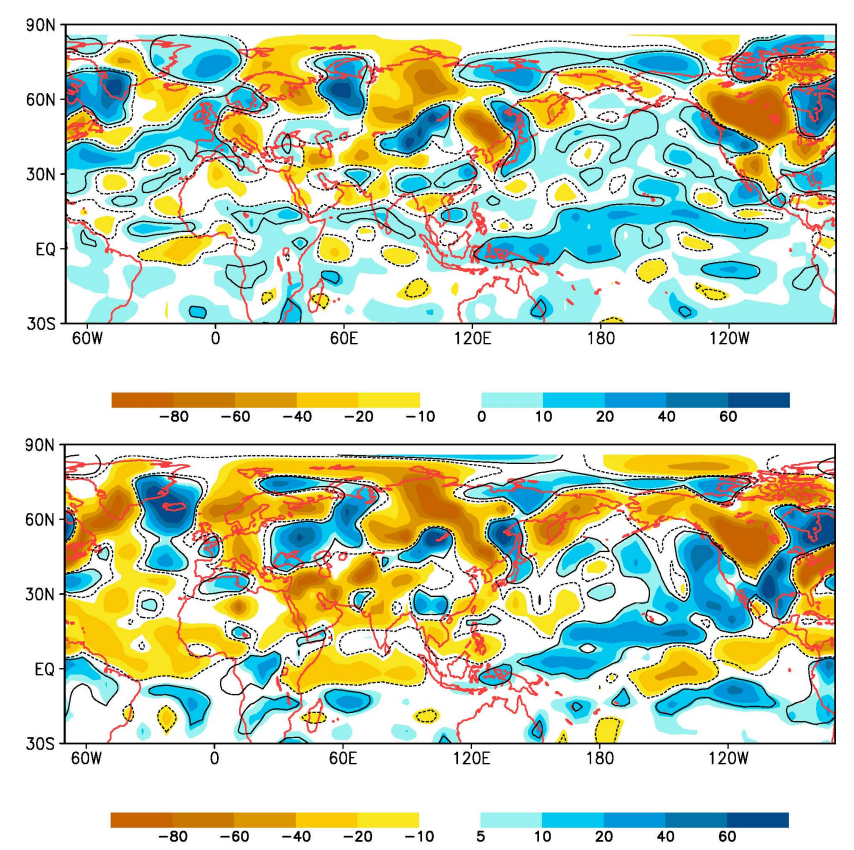

Fig. 9. July precipitation difference between experiment with and experiment without NA and EA ice sheets, for $495 \mathrm{ka} \mathrm{BP}$. (a)(upper panel) for small ice sheets, Exp. 7 minus Exp. 6; (b)(lower panel) for large ice sheets, Exp. 8 minus Exp. 6. The color shading indicates precipitation anomaly in $\mathrm{cm} /$ year and the black contour lines limit the regions where the anomalies are significant at more than the $95 \%$ confidence level.

when the NH summer is at perihelion (506 ka BP) than at aphelion ( $495 \mathrm{ka} \mathrm{BP})$. This might be due to the fact that the mean position of ITCZ is located more North in the 506 noice-sheet experiment than in the 495 one, because there is greater warming in the $\mathrm{NH}$ than in the $\mathrm{SH}$ at $506 \mathrm{ka} \mathrm{BP}$ in response to insolation. The more northern position of the ITCZ at $506 \mathrm{kaBP}$ makes it more sensitive to the ice sheets forcing, leading to a more pronounced displacement than at $495 \mathrm{ka}$ BP. Second, the wave train which propagates southeastwards from the EA ice sheet across the Asian continent and the North Pacific at $506 \mathrm{ka} \mathrm{BP}$, disappears at $495 \mathrm{ka} \mathrm{BP}$. Precipitation is reduced significantly over all the monsoon regions (Exp. 8), with 13\% less over north Africa, and 10\% over Asia $\left(70-120^{\circ} \mathrm{E}, 20-40^{\circ} \mathrm{N}\right)$ when compared to the noice-sheet experiment (Exp. 6). Over East China, the large ice sheets lead to a $6 \%$ precipitation decrease. At $495 \mathrm{ka} \mathrm{BP}$, the large ice sheets are responsible for a large anticyclonic anomaly at $800 \mathrm{hPa}$ over most of the Eurasian continent (Fig. 10) centered over central Siberia. At the same time, the northwestern Pacific High largely weakens. This anticyclonic anomaly over land and cyclonic anomaly over ocean largely reduce the land/ocean pressure gradient and generate a northwesterly wind anomaly over East China (Fig. 10). At the same time, the water vapor flux divergence increases over East Asia. All these impacts eventually weaken the

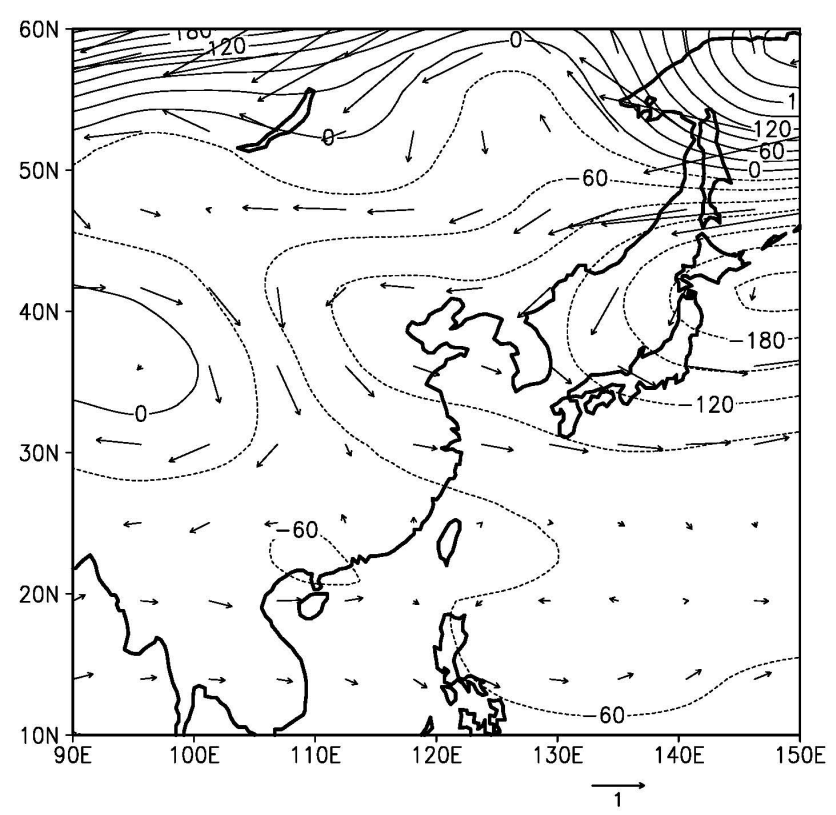

Fig. 10. Difference between Exp. 8 and Exp. 6 in July $800 \mathrm{hPa}$ geopotential $\left(\mathrm{m}^{2} \mathrm{~s}^{-2}\right)$ and wind $(\mathrm{m} / \mathrm{s})$ at $495 \mathrm{ka} \mathrm{BP}$ over East Asia.

EASM and reduce precipitation. Therefore, the impacts of the large ice sheets at $495 \mathrm{ka} \mathrm{BP}$ are markedly different from what happens at $506 \mathrm{ka} \mathrm{BP}$. In the 495 large-ice-sheet case, the ice sheets influence the EASM mainly through cooling the continent and reducing the land/ocean thermal contrast with no counteraction. On the other hand, in the 495-smallice-sheet, 506-small-ice-sheet and 506-large-ice-sheet cases, the ice sheets play a role on the EASM through both reducing the land/ocean thermal contrast which tends to weaken the monsoon, and a topographically induced wave train which tends to reinforces it. In these three cases, the reduction of the land/ocean thermal contrast is too small to overcome the wave train effect on the land/ocean pressure gradient.

The different responses of the EASM to the same ice sheets under two opposite precessional conditions indicate that insolation plays a very important role in shaping the ice sheets impacts including both the reduction of the land/ocean thermal contrast and the generation of the wave train. Although the mechanism of the wave train topographically induced by the EA ice sheet needs to be further investigated, the following explanation is tentatively given. There are actually three factors playing a role on shaping the precipitation over East China: a different warming due to the $\mathrm{NH}$ summer occurring either at perihelion or at aphelion, a cooling due to the existence of the ice sheets, and a wave train induced by the EA topography. The competition of these three factors creates a threshold beyond which monsoon activity is greatly reduced, a threshold which is easily reached when NH summer occurs at aphelion. Two cases are therefore existing. First, when the NH summer occurs at perihelion, 
the cooling due to the large ice sheet is partly attenuated by the warmer $\mathrm{NH}$ due to the larger insolation and therefore is not sufficient to reduce the large scale ascent over the continent. Moreover, the orographic effect generates a wave train which reinforces the ascent and so precipitation over East China. Second, when NH summer is at aphelion, the cooling effect due to the large ice sheets is sufficient to reduce the (weaker) convection over the continent. When the ice sheets are small, the orographic effect remains more important than the cooling effect and therefore the induced wave train still contributes to increase the precipitation over East China. When the ice sheets are sufficiently large (i.e. above the threshold), the cooling effect is stronger than orographic effect, preventing the formation of the wave train and therefore reducing precipitation over East China.

Although almost all the coldest peaks of the glacials correspond to NH summer at aphelion (low NH summer insolation) (Imbrie et al., 1984; Bassinot et al., 1994; Tiedemann et al., 1994; Shackleton, 2000; Lisiecki and Raymo, 2005; Berger, 1978), there are some periods within the glacials corresponding to $\mathrm{NH}$ summer at perihelion with a quite large $\mathrm{NH}$ summer insolation. During the last one million years, these specific periods occurred during MIS-6.5, -8.5, -10.3, $-12.3,-14.3,-16.3$ and -18.3 . According to our results, it is expected that during these specific periods the EASM would be strenghened not only by the high $\mathrm{NH}$ summer insolation but also by the ice sheets themselves. The same conclusion holds for the cooler or more glaciated interglacials such as MIS-7, -13, -15 and -17. Moreover, at some glacial peaks corresponding to $\mathrm{NH}$ summer at aphelion, precipitation over East China might be reinforced by the ice sheets whose volumes are below the threshold. It is significant indeed that a strengthened EASM has been found in the proxy records of China during the glacials MIS-6.5 (Rousseau and $\mathrm{Wu}$, 1999; Wang et al., 2008), MIS-10 and 12 (Wu et al., 2007; Rousseau et al., 2009), during the interstadial MIS-3 (Feng et al., 2007), and during the cooler interglacials MIS-13 and -15 (Guo et al., 1998; Guo et al., 2000; Yin and Guo, 2006).

\section{Conclusions}

The Earth system model of intermediate complexity, LOVECLIM, was used to investigate the climate response to insolation, the EA and NA ice sheets and their combined effects. Two precessional opposite situations have been used, one at $506 \mathrm{ka} \mathrm{BP}$ when $\mathrm{NH}$ summer occurs at perihelion, and the other at $495 \mathrm{ka} \mathrm{BP}$ when NH summer occurs at aphelion. Experiments with different sizes of the EA and NA under these two astronomical conditions lead to the following conclusions:

1. Confirming earlier results of sensitivity analysis to astronomical elements, the Earth is warmer when the $\mathrm{NH}$ summer occurs at perihelion rather than at aphelion, indicating that the NH plays a leading role in the Earth climate. The seasonal contrast in the $\mathrm{NH}(\mathrm{SH})$ is larger when the NH summer occurs at perihelion (aphelion). The NH monsoon precipitation is much more abundant in the NH summer at $506 \mathrm{ka} \mathrm{BP}$ due to its larger insolation than at $495 \mathrm{ka} \mathrm{BP}$.

2. When the EA and NA ice sheets are introduced, the cooling they induce over the whole Earth is mainly attributed to their albedo, and little to their height. In high latitudes, the cooling is mainly due to the subsequent increase of snow and sea ice. In mid-latitudes, it is due to the ascent of air topographically induced by the ice sheets. These ice sheets are not only at the origin of cooling anomalies but also of warming anomalies. Such warming anomalies are due to the subsidence of air resulting from either air flowing off the ice sheets, or remote atmospheric perturbations caused by the ice sheets. The amplitude of both cooling and warming anomalies gets larger when the size of the ice sheets increases.

3. Precipitation over different monsoon regions responds differently to the size of the ice sheets. Over North Africa and India, precipitation decreases with increasing ice sheet size due to the southward shift of the ITCZ, whatever the astronomical configuration is. However, the situation is more complicated over East Asia. The ice sheets play a role on the EASM through both reducing the land/ocean thermal contrast and generating a wave train which is topographically induced by the EA ice sheet. The first impact tends to reduce the land/ocean pressure gradient and finally the EASM. On the contrary, the second impact contributes to amplify the Asian land/ocean pressure gradient in summer and finally reinforces the monsoon. The presence of this wave train depends on the combined effect of the ice sheet size and insolation. When NH summer occurs at perihelion (506 ka BP), the EA topography is able to induce this wave train whatever the ice sheet size is, and this wave train plays a more important role on the EASM than the reduction of the land/ocean thermal contrast. Therefore, the ice sheets reinforce the summer precipitation over East China whatever their sizes are. However, when NH summer occurs at aphelion ( $495 \mathrm{ka} \mathrm{BP})$, there is a threshold in the ice volume beyond which the wave train fails to be induced. Therefore, within this threshold, the wave train effect is dominant and the ice sheets reinforce precipitation over East China. Beyond this threshold, the ice sheets weaken the EASM mainly through reducing the land/ocean thermal contrast. This different response of the EASM to the ice sheet sizes under different astronomical configurations might also partly explain the intensification of the EASM during some glacials or "cool" interglacials documented in the proxy records, a hypothesis which deserves more attention. 
Acknowledgements. We thank the anonymous reviewer and D.-D. Rousseau for their constructive comments to improve the manuscript. This work is supported by the 2008 European Research Council Advanced Grant EMIS $\left(\mathrm{N}^{\circ} 227348\right.$ of the Programme "Ideas"). Yin, Q. Z., is Chargée de Recherches (Postdoctoral Researcher) of F. R. S.-FNRS. (Belgian National Fund for Scientific Research). Crucifix, M., is a Research Associate with the F. R. S.-FNRS.

Edited by: M. Claussen

\section{References}

An, Z. S., Kukla, G., Porter, S. C., and Xiao, J. L.: Magnetic susceptibility evidence of monsoon variation on the Loess Plateau of central China during the last 130000 years, Quaternary Res., 36, 29-36, 1991.

An, Z. S., Kutzbach, J. E., Prell, W. L., and Porter, S. C.: Evolution of Asian monsoons and phased uplift of the Himalaya-Tibetan Plateau since late Miocene times, Nature, 411, 62-66, 2001.

Barnett, T. P., Damenil, K., Schlese, U., Roeckner, E., and Latif, M.: The effect of Eurasian snow cover on regional and global climate variations, J. Atmos. Sci., 46, 661-685, 1989.

Bassinot, F. C., Labeyrie, L. D., Vincent, E., Quidelleur, X., Shackleton, N. J., and Lancelot, Y.: The astronomical theory of climate and the age of the Brunhes-Matuyama magnetic reversal, Earth Planet. Sci. Lett., 126, 91-108, 1994.

Berger, A.: Long-term variations of daily insolation and Quaternary Climatic Changes, J. Atmos. Sci., 35(12), 2362-2367, 1978.

Berger, A., Loutre, M. F., and Tricot, C.: Insolation and Earth's orbital periods, J. Geophys. Res., 98(D6), 10341-10362, 1993.

Braconnot, P., Joussaume, S., de Noblet, N., and Ramstein, G.: Mid-Holocene and Last Glacial Maximum African monsoon changes as simulated within the Paleoclimate Modelling Intercomparison Project, Global Planet. Change, 26, 51-66, 2000.

Braconnot, P., Otto-Bliesner, B., Harrison, S., Joussaume, S., Peterchmitt, J.-Y., Abe-Ouchi, A., Crucifix, M., Driesschaert, E., Fichefet, Th., Hewitt, C. D., Kageyama, M., Kitoh, A., Laîné, A., Loutre, M.-F., Marti, O., Merkel, U., Ramstein, G., Valdes, P., Weber, S. L., Yu, Y., and Zhao, Y.: Results of PMIP2 coupled simulations of the Mid-Holocene and Last Glacial Maximum Part 1: experiments and large-scale features, Clim. Past, 3, 261277, 2007, http://www.clim-past.net/3/261/2007/.

Broccoli, A. J., Dahl, K. A., and Stouffer, R. J.: Response of the ITCZ to Northern Hemisphere Cooling, Geophys. Res. Lett., 33, L01702, doi:10.1029/2005GL024546, 2006.

Brovkin, V., Ganapolski, A., and Svirezhev, Y.: A continuous climate-vegetation classification for use in climate-biosphere studies, Ecol. Model., 101, 251-261, 1997.

Chiang, J. C. H. and Bitz, C. M.: Influence of high latitude ice cover on the marine Intertropical Convergence Zone, Clim. Dynam., 25(5), 477-496, 2005.

Chiang, J. C. H., Biasutti, M., and Battisti, D. S.: Sensitivity of the Atlantic intertropical convergence zone to last glacial maximum boundary conditions, Paleoceanography, 18(4), 1094, doi:10.1029/2003PA000916, 2003.
Clemens, S. C., Murray, D. W., and Prell, W. L.: Nonstationary Phase of the Plio-Pleistocene Asian Monsoon, Science, 274, 943-948, 1996.

Clemens, S., Prell, W., Murray, D., Shimmield, G., and Weedon, G.: Forcing mechanisms of the Indian Ocean monsoon, Nature, 353, 720-725, 1991.

Claussen, M., Mysak, L. A., Weaver, A. J., Crucifix, M., Fichefet, T., Loutre, M.-F., Weber, S. L., Alcamo, J., Alexeev, V. A., Berger, A., Calov, R., Ganopolski, A., Goosse, H., Lohman, G., Lunkeit, F., Mokhov, I. I., Petoukhov, V., Stone, P., and Wang, Z.: Earth system models of intermediate complexity: Closing the gap in the spectrum of climate system models, Clim. Dynam., 18, 579-586, 2002.

Crucifix, M. and Loutre, M. F.: Transient simulations over the last interglacial period (126-115 kyr BP): feedback and forcing analysis, Clim. Dynam., 19, 417-433, 2002.

deMenocal, P. B.: Plio-Pleistocene African Climate, Science, 270, 53-59, 1995.

Ding, Y., Sikka, D. R.: Synoptic systems and weather, in: The Asian Monsoon, edited by: Wang, B., Springer Praxis, Springer, Berlin Heidelberg, 131-202, 2006.

Driesschaert, E., Fichefet, T., Goosse, H., Huybrechts, P., Janssens, I., Mouchet, A., Munhoven, G., Brovkin, V., and Weber, S. L.: Modeling the influence of Greenland ice sheet melting on the Atlantic meridional overturning circulation during the next millennia, Geophys. Res. Lett., 34, L10707, doi:10.1029/2007GL029516, 2007.

Enomoto, T., Hoskin, B., and Matsuda, Y.: The formation mechanism of the Bonin high in August, Q. J. Roy. Meteor. Soc., 129, 157-178, 2003.

Felzer, B., Oglesby, R. J., Webb III, T., and Hymand, E.: Sensitivity of a general circulation model to changes in northern hemisphere ice sheets, J. Geophys. Res., 101, 19077-19092, 1996.

Feng, Z.-D., Tang, L. Y., Ma, Y. Z., Zhai, Z. X., Wu, H. N., Li, F., Zou, S. B., Yang, Q. L., Wang, W. G., Derbyshire, E., and Liu, K.-B.: Vegetation variations and associated environmental changes during marine isotope stage 3 in the western part of the Chinese Loess Plateau, Palaeog. Palaeoclim. Palaeoec., 246, 278-291, 2007.

Goes, J. I., Thoppil, P. G., do R Gomes, H., and Fasullo, J. T.: Warming of the Eurasian Landmass Is Making the Arabian Sea More Productive, Science, 308(5721), 545-547, 2005.

Goosse, H. and T. Fichefet: Importance of ice-ocean interactions for the global ocean circulation: a model study, J. Geophys. Res., 104(C10), 23337-23355, 1999.

Grose, W. L. and Hoskins, B. J.: On the Influence of Orography on Large-Scale Atmospheric Flow, J. Atmos. Sci., 36, 223-234, 1979.

Guo, Z. T., Berger, A., Yin, Q. Z., and Qin, L.: Strong asymmetry of hemispheric climates during MIS-13 inferred from correlating China loess and Antarctica ice records, Clim. Past, 5, 21-31, 2009 , http://www.clim-past.net/5/21/2009/.

Guo, Z. T., Liu, T. S., Fedoroff, N., Wei, L. Y., Ding, Z. L., Wu, N. Q., Lü, H. Y., Jiang, W. Y., and An, Z. S.: Climate extremes in Loess of China coupled with the strength of Deep-Water Formation in the North Atlantic, Global Planet. Change, 18, 113-128, 1998.

Guo, Z. T., Biscaye, P., Wei, L. Y., Chen, X. F., Peng, S. Z., and Liu, 
T. S.: Summer monsoon variations over the last 1.2 Ma from the weathering of loess-soil sequences in China, Geophys. Res. Lett., 27, 1751-1754, 2000.

Hoskins, B. J. and Karoly, D. J.: The steady linear response of a spherical atmosphere to thermal and orographic forcing, J. Atmos. Sci., 38, 1179-1196, 1981.

Imbrie, J., Hays, J. D., Martinson, D. G., McIntyre, A., Mix, A. C., Morley, J. J., Pisias, N. G., Prell, W. L., and Shackleton, N. J.: The orbital theory of Pleistocene climate: support from a revised chronology of the marine $\delta^{18} \mathrm{O}$ record, in: Milankovitch and Climate, Part 1, edited by: Berger, A. L., Imbrie, J., Hays, J., et al., D. Reidel Pub. Co., 269-305, 1984.

IPCC-Group I: Climate Change 2007: the Physical Science Basis, Summary for Policymakers, Contribution of Working Group I to the Fourth Assessment Report of IPCC, IPCC secretariat, C/O WMO, Geneva, February, 2007.

Jouzel, J., Masson-Delmotte, V., Cattani, O., Dreyfus, G., Falourd, S., Hoffmann, G., Minster, B., Nouet, J., Barnola, J. M., Chappellaz, J., Fischer, H., Gallet, J. C., Johnsen, S., Leuenberger, M., Loulergue, L., Luethi, D., Oerter, H., Parrenin, F., Raisbeck, G., Raynaud, D., Schilt, A., Schwander, J., Selmo, E., Souchez, R., Spahni, R., Stauffer, B., Steffensen, J. P., Stenni, B., Stocker, T. F., Tison, J. L., Werner, M., and Wolff, E. W.: Orbital and Millennial Antarctic Climate Variability over the Past 800000 Years, Science, 317, 793-796, 2007.

Kageyama, M. and Valdes, P. J.: Impact of the North American ice-sheet orography on the Last Glacial Maximum eddies and snowfall, Geophys. Res. Lett., 27(10), 1515-1518, 2000.

Kitoh, A., Murakami, S., and Koide, H.: A simulation of the Last Glacial Maximum with a coupled atmosphere-ocean GCM, Geophys. Res. Lett., 28, 2221-2224, 2001.

Kukla, J. and Kukla, H. J.: Increased surface albedo in the northern hemisphere, Science, 183, 709-714, 1974.

Kukla, G., Berger, A., Lotti, R., and Brown, J.: Orbital signature of interglacials, Nature, 290, 295-300, 1981.

Kutzbach, J. E., Liu, X. D., Liu, Z. Y., and Chen, G. S.: Simulation of the evolutionary response of global summer monsoons to orbital forcing over the past 280000 years, Clim. Dynam., 30, 567-579, 2008.

Kutzbach J. E., Gallimore, R., Harrison, S., Behling, P., Selin, R., and Laarif, F.: Climate and biome simulations for the past 21000 years, Quaternary Sci. Rev., 17(6-7), 473-506, 1998.

Kutzbach, J. E. and Guetter, P. J.: The influence of changing orbital parameters and surface boundary conditions on climate simulations for the past 18000 years, J. Atmos. Sci., 43, 1726-1759, 1986.

Lambeck, K., Yokoyama, Y., Johnston, P., and Purcell, A.: Global ice volumes at the last glacial maximum and early lateglacial, Earth Planet. Sci. Lett., 181, 513-527, 2000.

Lisiecki, L. E. and Raymo, M. E.: A Pliocene-Pleistocene stack of 57 globally distributed benthic delta $\delta^{18} \mathrm{O}$ records, Paleoceanography, 20(1), PA1003, doi:10.1029/2004PA001071, 2005.

Liu, X. D., Liu, Z. Y., Kutzbach, J. E., Clemens, S. C., and Prell, W. L.: Hemispheric insolation forcing of the Indian Ocean and Asian monsoon: local versus remote impacts, J. Climate, 19, 6195-6208, 2006.

Liu, Z., Trentesaux, A., Clemens, S. C., Colin, C., Wang, P., Huang, B., and Boulay, S.: Clay mineral assemblages in the northern South China Sea: implications for East Asian monsoon evolution over the past 2 million years, Mar. Geol., 201, 133-146, 2003.

Loulergue, L., Schilt, A., Spahni, R., Masson-Delmotte, V., Blunier, T., Lemieux, B., Barnola, J. M., Raynaud, D., Stocker, T. F., and Chappellaz, J.: Orbital and millennial-scale features of atmospheric $\mathrm{CH}_{4}$ over the past 800000 years, Nature, 453, 383386, 2008.

Luthi, D., Le Floch, M., Bereiter, B., Blunier, T., Barnola, J. M., Siegenthaler, U., Raynaud, D., Jouzel, J., Fischer, H., Kawamura, K., and Stocker, T. F.: High-resolution carbon dioxide concentration record 650000-800000 years before present, Nature, 453, 379-382, 2008.

Manabe, S. and Broccoli, A. J.: The influence of continental ice sheets on the climate of an ice age, J. Geophys. Res., 90, 21672190, 1985.

Masson, V., Braconnot, P., Jouzel, J., de Noblet, N., Cheddadi, R., and Marchal, O.: Simulation of intense monsoons under glacial conditions, Geophys. Res. Lett., 27, 1747-1750, 2000.

Mélières, M. A., Rossignol-Strick, M., and Malaizé, B.: Relation between low latitude insolation and $\delta^{18} \mathrm{O}$ change of atmospheric oxygen for the last $200 \mathrm{kyrs}$, as revealed by Mediterranean sapropels, Geophys. Res. Lett., 24(10), 1235-1238, 1997.

Opsteegh, J. D., Haarsma, R. J., Selten, F. M., and Kattenberg, A.: ECBILT: A dynamic alternative to mixed boundary conditions in ocean models, Tellus, 50A, 348-367, 1998.

Overpeck, J., Anderson, D., Trumbore, S., and Prell, W.: The southwest Indian Monsoon over the last 18000 years, Clim. Dynm., 12, 213-225, 1996.

Paterson, W. S. B.: The Physics of Glaciers, Pergamon, Tarrytown, N.Y., 1994.

Peltier, W. R.: Global glacial isostasy and the surface of the ice-age Earth: the ICE-5G (VM2) model and GRACE, Annu. Rev. Earth Pl. Sc., 32, 111-149, 2004.

Peltier, W. R.: Ice age paleotopography, Science, 265, 195-201, 1994.

Rind, D.: Components of the ice age circulation, J. Geophys. Res., 92, 4241-4281, 1987.

Rossignol-Strick, M.: African monsoons, an immediate climate response to orbital insolation, Nature, 304, 46-49, 1983.

Rossignol-Strick, M., Paterne, M., Bassinot, F. C., Emeis, K.-C., and De Lange, G. J.: An unusual mid-Pleistocene monsoon period over Africa and Asia, Nature, 392, 269-272, 1998.

Rousseau, D. D. and Wu, N.: Mollusk record of monsoon variability during the L2-S2 Cycle in the Luochuan loess sequence, China, Quaternary Res., 52, 286-292, 1999.

Rousseau, D.-D., Wu, N., Pei, Y., and Li, F.: Three exceptionally strong East-Asian summer monsoon events during glacial times in the past $470 \mathrm{kyr}$, Clim. Past, 5, 157-169, 2009, http://www.clim-past.net/5/157/2009/.

Shackleton, N. J.: The 100 000-year Ice-Age Cycle identified and found to lag temperature, carbon dioxide and orbital eccentricity, Science, 289, 1897-1902, 2000.

Siegenthaler, U., Stocker, T. F., Monnin, E., Lüthi, D., Schwander, J., Stauffer, B., Raynaud, D., Barnola, J.-M., Ficher, H., MassonDelmott, V., and Jouzel, J.: Stable carbon cycle-climate relationship during the late Pleistocene, Science, 310, 1313-1317, 2005.

Sirocko, F., Sarnthein, M., Lange, H., and Erlenkeuser, H.: Atmospheric summer circulation and coastal upwelling in the Arabian Sea during the Holocene and the last glaciation, Quaternary Res. 36, 72-93, 1991. 
Spahni, R., Chappellaz, J., Stocker, T. F., Loulergue, L., Hausammann, G., Kawamura, K., Fluckiger, J., Schwander, J., Raynaud, D., Masson-Delmotte, V., and Jouzel, J.: Atmospheric Methane and Nitrous Oxide of the Late Pleistocene from Antarctic Ice Cores, Science, 310, 1317-1321, 2005.

Street-Perrott, F. A. and Perrott, R. A.: Abrupt climate fluctuations in the tropics: the influence of Atlantic Ocean circulation, Nature, 343, 607-612, 1990.

Stein, U. and Alpert, P.: Factor Separation in Numerical Simulations, J. Atmos. Sci., 50(14), 2107-2115, 1993.

Tiedemann, R., Sarntheim, M., and Shackleton, N. J.: Astronomic timescale for the Pliocene Atlantic $\delta^{18} \mathrm{O}$ and dust flux records of Ocean Drilling Program site 659, Paleoceanography, 9, 619-638, 1994.

Trenberth, K. E., Hurrell, J. W., and Stepaniak, D. P.: The Asian monsoon: Global perspectives, in: The Asian Monsoon, edited by: Wang, B., Springer Praxis, Springer, Berlin, Heidelberg, 6787, 2006.

Van Campo, E., Duplessy J. C., and Rossignol-Strick, M.: Climatic conditions deduced from a $150 \mathrm{Kyr}$ oxygen isotope-pollen record from the Arabian Sea, Nature, 296, 56-59, 1982.

Vernekar, A. D. and Shukla, J.: The effect of Eurasian snow cover on the Indian monsoon, J. Climate, 8, 248-266, 1995.

Wang, B., Clemens, S. C., and Liu, P.: Contrasting the Indian and East Asian monsoons: implications on geologic timescales, Mar. Geol., 201, 5-21, 2003.

Wang, P. X.: Global monsoon in a geological perspective, Chinese Sci. Bull., 54(7), 1113-1136, 2009.
Wang, Y., Cheng, H., Edwards, R. L., Kong, X., Shao, X., Chen, S., Wu, J., Jiang, X., Wang, X., and An, Z.: Millenial- and orbitalscale changes in the East Asian monsoon over the past 224000 years, Science, 451, 1090-1093, 2008.

Webster, P. J., Magana, V. O., Palmer, T. N., Shukla, J., Tomas, R. A., Yanai, M., and Yasunari, T.: Monsoons: processes, predictability and the prospects for prediction, J. Geophys. Res., 103(C7), 14451-14510, 1998.

Wu, N. Q., Chen X. Y., Rousseau, D. D., Li, F. J., Pei, Y. P., and Wu, B.: Climatic conditions recorded by terrestrial mollusk assemblages in the Chinese Loess Plateau during marine Oxygen Isotope Stages 12-10, Quaternary Sci. Rev., 26, 1884-1896, 2007.

Yanase, W. and Abe-Ouchi, A.: The LGM surface climate and atmospheric circulation over East Asia and the North Pacific in the PMIP2 coupled model simulations, Clim. Past, 3, 439-451, 2007, http://www.clim-past.net/3/439/2007/.

Yin, Q. Z. and Guo, Z. T.: Mid-Pleistocene vermiculated red soils in southern China as an indication of unusually strengthened East Asian monsoon, Chinese Sci. Bull., 51(2), 213-220, 2006.

Yin, Q. Z. and Guo, Z. T.: Strong summer monsoon during the cool MIS-13, Clim. Past, 4, 29-34, 2008, http://www.clim-past.net/4/29/2008/.

Yin, Q. Z., Berger, A., Driesschaert, E., Goosse, H., Loutre, M. F., and Crucifix, M.: The Eurasian ice sheet reinforces the East Asian summer monsoon during the interglacial 500000 years ago, Clim. Past, 4, 79-90, 2008, http://www.clim-past.net/4/79/2008/. 